\section{GOSHAWK - SNOWSHOE HARE ENCOUNTER}

KENT BRACE, R.R. 3, Saskatoon, Saskatchewan. S7K 3J6

On 15 January 1983, my wife, our two children and I observed a Goshawk pursue and kill a Snowshoe Hare. The dramatic encounter transpired in a strip of bush (willow, rose, Black Poplar, Chokecherry and Wolf Willow) located about $10 \mathrm{~m}$ from our Pike Lake, Saskatchewan, home.

One of the children noticed the Goshawk sitting in a tree just outside our kitchen window. During the next 45 to 60 minutes, the large accipiter harassed a Snowshoe Hare located in the thick understory below.

The bush, although only about $10 \mathrm{~m}$ wide, was too thick for the Goshawk to negotiate at high speeds. The hawk employed an interesting tactic with highly successful results. On four occasions the bird dropped down through the trees, landing a few feet from the hare. The Snowshoe responded by darting along inside the bush at full speed. The Hawk then pursued the hare, flying just over the tree tops. The hare ran about 20 to $30 \mathrm{~m}$ on each occasion and then stopped, remaining inside the bush. The hare ran back and forth, staying within a patch 50 to $60 \mathrm{~m}$ long. The hawk would perch over the hare, occasionally cocking its head to view its prey.

These vigorous pursuits, although short in duration, seemed to tax the hawk, as expelled air was visible following the chases. I am not certain how long the hunt had been is progress before we became aware of it. It was not possible to detect adverse effects to the hare, at least not as long as it remained in the bush. Finally the hare scurried out of the bush and attempted to cross a small clearing. The Goshawk pounced on it and killed it.

My wife feeds Snowshoe Hares at our back door. During extremely cold periods, up to five animals can be seen at dawn and dusk. We have seen a Goshawk hunting the narrow strip of bush on two other occasions since 15 January.

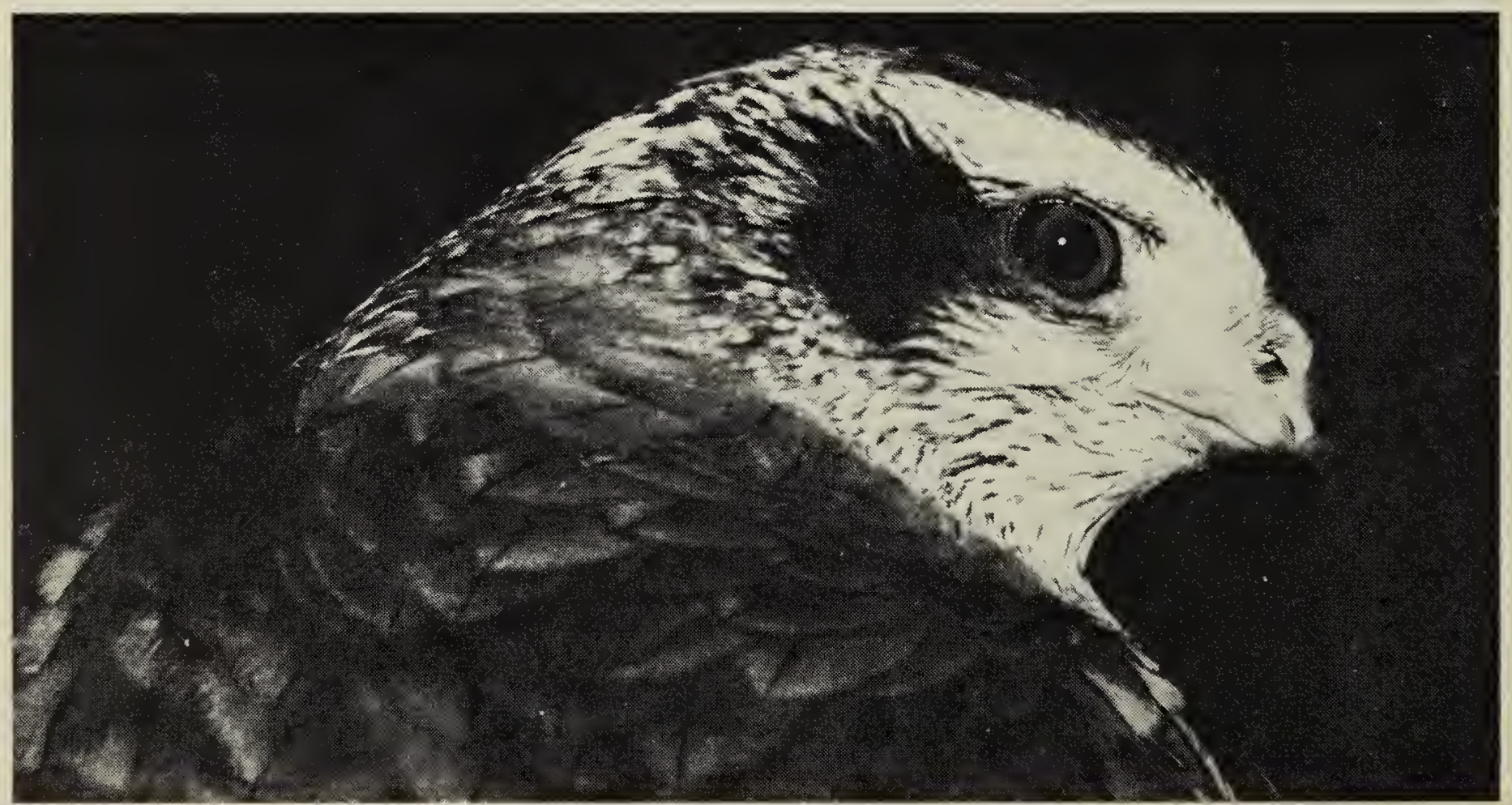

